\title{
Effect Comparison of Double-stranded Quaternary Disinfectant Wipes and Chlorine Disinfectant of Sterilizing the Surface of the Operating Room
}

\author{
Changxia Cheng, Ao Jiang*, Changjie Cheng \\ Department of Surgery, China - Japan Friendship Hospital, Jilin University, Jilin, 130000, China \\ *corresponding author’s email: 1021161418@qq.com
}

Keywords: Double-Stranded Quaternary Disinfectant Wipes; Chlorine Disinfectant; Operating Room; Sterilizing Effect

\begin{abstract}
Objective: To discuss the effect of double-stranded quaternary disinfectant wipes and chlorine disinfectant of sterilizing the surface of the operating room, and provide the basis for the operating room to choose the right way to disinfect. Method: 50 cases of operating table, instrument table, shadowless were given $2000 \mathrm{mg} / \mathrm{L}$ double-stranded quaternary disinfectant wipes and $500 \mathrm{mg} / \mathrm{L}$ chlorine disinfectant, and the surface of them were sampled and cultured before disinfection and instant, $30 \mathrm{~min}, 1 \mathrm{~h}$ after disinfection. The number of bacterial colonies, sterilization rate and disinfection cost before disinfection and different time points after disinfection of the different disinfection methods were observed. Results: The number of bacterial colonies of operating table, instrument table, shadowless before disinfection were respectively (35.9 \pm 2.6$) \mathrm{cfu} /$ $\mathrm{cm} 2$, $(46.0 \pm 2.9) \mathrm{cfu} / \mathrm{cm} 2$, $(78.3 \pm 6.4) \mathrm{cfu} / \mathrm{cm} 2$, and the number of instant, $30 \mathrm{~min}, 1 \mathrm{~h}$ after disinfection were significantly lower than before disinfection, the differences were statistically significant $(P<0.05)$. The number of bacterial colonies of double-stranded quaternary disinfectant wipes at different time points after disinfection were significantly lower than chlorine disinfectant, the differences were statistically significant $(P<0.05)$;Disinfection effect of Escherichia coli, Staphylococcus aureus using double-stranded quaternary disinfectant wipes were better than chlorine disinfectant. Cost of double-stranded quaternary disinfectant wipes every disinfection was 0.6 yuan, and was lower than 0.9 yuan of the chlorine disinfectant. Conclusion: When sterilizing the surface of the operating room, double-stranded quaternary disinfectant wipes and chlorine disinfectant both can achieve better results, but the former is superior to the latter, and the former has the advantages of lower cost, simple and convenient, and is worthy of popularization in operating room.
\end{abstract}

\section{Introduction}

With the rapid development of the economy and society and the continuous advancement of modern medicine, hospital infection has become a very important issue. Infection not only increases the economic burden and suffering of patients, but also threatens the life and health of patients. The operating room, which is an important part of the hospital, is an important place to rescue critically ill patients and perform surgery. It is prone to various infections [1] In recent years, with the continuous improvement of medical technology, many hospitals in China have established operating rooms with clean air functions, which significantly improve the air quality and air cleanliness in the operating room, control the infection in the operating room, and reduce the complications associated with infection. Other aspects have played an important role [2]. However, only purifying the air can not eliminate the bacteria on the surface of the operating room, and can not minimize the incidence of infection in patients [3]. Therefore, effective sterilization of the surface of the operating room and providing a good environment for the patient are important measures to reduce infection. Chlorine-containing disinfectants are widely welcomed by medical institutions because of their low price, convenient disinfection and high bactericidal effect. However, with the increasing awareness of environmental protection, the continuous improvement of disinfection methods, the strong irritancy of chlorine-containing disinfectants and The pollution of the environment has 
gradually attracted people's attention, and the double-chain quaternary ammonium salt disinfectant can kill the bacterial propagules and kill the lipophilic virus. The biochemical properties are relatively stable, and it is more suitable for surface disinfection of environmental objects [4- 5]. In this study, 50 cases of operating table, instrument table and shadowless lamp in the operating room of our hospital were selected for disinfection. Two different methods were given to explore the surface of the operating room containing double-stranded quaternary ammonium disinfectant wipes and chlorine disinfectant. The sterilization effect provides a basis for selecting the appropriate disinfection method for the operating room. The results of the analysis are now reported as follows:

\section{Materials and Methods}

\subsection{Materials}

We selected 50 samples of operating table, instrument table and shadowless lamp in the operating room from October 2014 to December 2014 in our hospital as the research object. $2000 \mathrm{mg} / \mathrm{L}$ double-stranded quaternary ammonium salt disinfectant wipes were provided by Shanghai Zhongyou Pharmaceutical Co., Ltd. The 500mg/L chlorine disinfectant is provided by the operating room of the hospital. The laboratory's laboratory provides sterile cotton swabs and other reagents after disinfection.

\subsection{Disinfection Method}

Each subject of the study was divided and labeled into two areas (the same area of the two areas, $8 \mathrm{~cm} \times 8 \mathrm{~cm}$ ), respectively, using a double-stranded quaternary ammonium disinfection wipes and chlorine disinfectant for disinfection, disinfection time is 20 s.

\subsection{Sampling Method}

Before and after disinfection, the sterilized specification plate is used for sampling. Before disinfection, the cotton swabs with sterile physiological saline are used for rubbing and rotating in the sterilization specification plate, and then the parts touched are removed and put into the package. The test tube was sent to an eluent tube containing about $5 \mathrm{~mL}$ of sterile physiological saline. Immediately after disinfection, $30 \mathrm{~min}, 1 \mathrm{~h}$, the same method was used for sampling, but the solution and eluent extracted by the cotton swab were respectively neutralizing agents of the corresponding disinfectant.

\subsection{Observation Indicators}

Observe and record the number of bacterial colonies, sterilization rate and disinfection cost of different disinfection methods at different time points before and after disinfection.

\subsection{Statistical Analysis}

The data were analyzed and analyzed by SPSS 18.0. The measurement data were expressed as mean \pm standard deviation ( $\pm \mathrm{s}$ ), and t test was used. The count data was expressed by rate. The test was used, and the difference was statistically significant at $\mathrm{P}<0.05$. .

\section{Results}

\subsection{The Carrier Condition of the Three Groups of Tested Objects before and after the Intervention of the Corresponding Disinfection Method.}

Before disinfection, the number of bacterial colonies contained in the operating table, instrument table, and shadowless lamp were: $(35.9 \pm 2.6) \mathrm{cfu} / \mathrm{cm} 2,(46.0 \pm 2.9) \mathrm{cfu} / \mathrm{cm} 2,(78.3 \pm 6.4) \mathrm{cfu} /$ cm2, two disinfectants The number of colonies immediately after disinfection, $30 \mathrm{~min}, 1 \mathrm{~h}$ was significantly lower than that before disinfection, the difference was statistically significant $(\mathrm{P}<0.05)$; the bacterial colonies containing double-stranded quaternary ammonium disinfectant wipes at various time points after disinfection The number was significantly lower than the chlorine 
disinfectant, the difference was statistically significant $(\mathrm{P}<0.05)$; the specific results are shown in Table 1, Table 2:

Table 1 Comparison of bacterial colony number and sterilization rate before and after intervention of two disinfection methods

\begin{tabular}{|c|c|c|c|c|c|c|c|c|c|}
\hline \multirow[b]{2}{*}{ Disinfectant } & \multirow[b]{2}{*}{ Test object } & \multirow[b]{2}{*}{ Quantity } & \multirow{2}{*}{$\begin{array}{l}\text { Number } \\
\text { of } \\
\text { colonies } \\
\text { before } \\
\text { disinfection } \\
\left(\mathrm{cfu} / \mathrm{cm}^{2}\right)\end{array}$} & \multicolumn{2}{|c|}{$\begin{array}{l}\text { Immediately after } \\
\text { disinfection }\end{array}$} & \multicolumn{2}{|c|}{$\begin{array}{l}30 \text { minutes after } \\
\text { disinfection }\end{array}$} & \multicolumn{2}{|c|}{$\begin{array}{l}1 \text { hour after } \\
\text { disinfection }\end{array}$} \\
\hline & & & & $\begin{array}{c}\text { Number } \\
\text { of } \\
\text { colonies } \\
\left(\mathrm{cfu} / \mathrm{cm}^{2}\right)\end{array}$ & $\begin{array}{l}\text { Sterilization } \\
\text { rate(\%) }\end{array}$ & $\begin{array}{l}\text { Number } \\
\text { of } \\
\text { colonies } \\
\left(\mathrm{cfu} / \mathrm{cm}^{2}\right)\end{array}$ & $\begin{array}{l}\text { Sterilization } \\
\text { rate(\%) }\end{array}$ & $\begin{array}{l}\text { Number } \\
\text { of } \\
\text { colonies } \\
\left(\mathrm{cfu} / \mathrm{cm}^{2}\right)\end{array}$ & $\begin{array}{c}\text { Sterilization } \\
\text { rate(\%) }\end{array}$ \\
\hline \multirow{3}{*}{$\begin{array}{c}\text { Double-chain } \\
\text { quaternary } \\
\text { ammonium } \\
\text { disinfection } \\
\text { wipes }\end{array}$} & $\begin{array}{c}\text { Shadowless } \\
\text { lamp }\end{array}$ & 50 & $78.3 \pm 6.4$ & $0.3 \pm 0.0$ & 99.62 & $2.2 \pm 1.1$ & 97.19 & $5.9 \pm 2.2$ & 92.46 \\
\hline & $\begin{array}{l}\text { Operating } \\
\text { table }\end{array}$ & 50 & $35.9 \pm 2.6$ & $0.2 \pm 0.0$ & 99.44 & $1.2 \pm 0.7$ & 96.66 & $3.8 \pm 1.9$ & 89.42 \\
\hline & $\begin{array}{l}\text { Instrument } \\
\text { table }\end{array}$ & 50 & $46.0 \pm 2.9$ & $0.2 \pm 0.1$ & 99.57 & $1.6 \pm 0.9$ & 96.52 & $4.3 \pm 2.1$ & 90.65 \\
\hline \multirow{3}{*}{$\begin{array}{l}\text { Chlorine } \\
\text { disinfectant }\end{array}$} & $\begin{array}{c}\text { Shadowless } \\
\text { lamp }\end{array}$ & 50 & $78.3 \pm 6.4$ & $0.4 \pm 0.3$ & 99.49 & $3.2 \pm 1.5$ & 95.91 & $7.3 \pm 3.2$ & 90.68 \\
\hline & $\begin{array}{l}\text { Operating } \\
\text { table }\end{array}$ & 50 & $35.9 \pm 2.6$ & $0.4 \pm 0.0$ & 99.03 & $1.8 \pm 0.8$ & 94.99 & $5.0 \pm 2.7$ & 86.07 \\
\hline & $\begin{array}{c}\text { Instrument } \\
\text { table }\end{array}$ & 50 & $46.0 \pm 2.9$ & $0.3 \pm 0.1$ & 99.35 & $2.0 \pm 1.1$ & 95.65 & $6.1 \pm 3.1$ & 86.74 \\
\hline
\end{tabular}

Note: $\mathrm{P}$ is $<0.05$ compared with pre-disinfection

Table 2 Comparison results between groups of two disinfectants

\begin{tabular}{ccccccc}
\hline Time point & \multicolumn{2}{c}{ Shadowless lamp } & \multicolumn{2}{c}{ Operating table } & \multicolumn{2}{c}{ Instrument table } \\
\cline { 2 - 7 } & $\mathrm{t}$ & $\mathrm{P}$ & $\mathrm{t}$ & $\mathrm{P}$ & $\mathrm{t}$ & $\mathrm{P}$ \\
\hline $\begin{array}{c}\text { Immediately after } \\
\text { disinfection }\end{array}$ & 2.357 & 0.018 & 1.000 & 0.000 & 5.000 & 0.000 \\
$\begin{array}{c}30 \text { minutes after } \\
\text { disinfection }\end{array}$ & 3.801 & 0.000 & 3.991 & 0.000 & 1.990 & 0.047 \\
$\begin{array}{c}1 \text { hour after } \\
\text { disinfection }\end{array}$ & 2.674 & 0.008 & 2.570 & 0.010 & 3.399 & 0.001 \\
\hline
\end{tabular}

\subsection{Comparison of the Results of Disinfection of Different Experimental Bacteria by Two Disinfection Methods.}

After two different methods of disinfection on the same equipment, the disinfection effect of double-stranded quaternary ammonium salt disinfectant on Escherichia coli and Staphylococcus aureus is better than that of chlorine-containing disinfectant. The specific results are shown in Table 3:

Table 3

\begin{tabular}{|c|c|c|c|c|c|c|}
\hline \multirow{2}{*}{$\begin{array}{l}\text { Bacterial } \\
\text { species }\end{array}$} & \multicolumn{3}{|c|}{$\begin{array}{l}\text { Containing double-stranded } \\
\text { ammonium salt disinfectant wipes }\end{array}$} & \multicolumn{3}{|c|}{ Chlorine disinfectant } \\
\hline & $\begin{array}{l}\text { Before } \\
\text { disinfection }\end{array}$ & $\begin{array}{l}\text { After } \\
\text { disinfection }\end{array}$ & Kill rate & $\begin{array}{l}\text { Before } \\
\text { disinfection }\end{array}$ & $\begin{array}{l}\text { After } \\
\text { disinfection }\end{array}$ & Kill rate \\
\hline Staphylococcus & 23 & 0.07 & 99.69 & 23 & 0.15 & 99.35 \\
\hline Staphylococcus & 12 & 0.02 & 99.83 & 12 & 0.03 & 99.75 \\
\hline
\end{tabular}




\subsection{Comparison of Cost Results between Two Disinfection Methods.}

At each disinfection, the cost of the double-stranded quaternary ammonium disinfectant wipes is 0.6 yuan, and the chlorine disinfectant is 0.9 yuan. The former cost is lower than the latter. The specific results are shown in Table 4:

Table 4 Comparison of cost results for different disinfection methods (yuan/time)

\begin{tabular}{lll}
\hline cost & $\begin{array}{l}\text { Containing double-stranded } \\
\text { quaternary ammonium } \\
\text { disinfectant wipes }\end{array}$ & Chlorine disinfectant \\
\hline Artificial & 0.3 & 0.4 \\
small towel & $/$ & $/$ \\
Wipes & 0.2 & 0.5 \\
disinfectant & 0.1 & 0.9 \\
total & 0.6 & \\
\hline
\end{tabular}

\section{Discussion}

The sterilization of the surface of the operating room is an integral part of disinfection and isolation, and is an important part of hospital prevention of infection. Disinfection and disinfection of the surface of the operating room means killing all the microorganisms present on the surface and preventing delayed healing of the wounds caused by contact with the surface of the infected pathogen. This is an important preventive measure [6]. According to the national requirements for the sanitation and sanitation of medical institutions, the environment of the operating room belongs to the Class I environment, and the bacteria on the surface of the operating room cannot exceed 5 $\mathrm{cfu} / \mathrm{cm} 2$. If this limit is exceeded, it will increase the chance of infection in the patient's incision or wound, and increase the difficulty of treatment of the disease. The pathogenic microorganisms on the surface of the operating room cause the infection of the patient mainly related to the type of pathogenic bacteria, the degree of environmental cleanliness, the virulence of bacteria and the number of bacteria, and the effect of disinfection and isolation. The most important method is disinfection. And the type of disinfectant selected [7]. In many hospitals, due to the large number of patients, the number of operating rooms is not enough. In order to perform surgery on patients in time, there are often cases of continuous operation. At this time, it is necessary to timely and effectively disinfect the disinfectant which is convenient for disinfection, has little irritating to the environment and the patient, and is not corrosive [8]. At present, the commonly used disinfection methods in the clinic include double-stranded quaternary ammonium salt disinfectant wipes and chlorine-containing disinfectants. Both methods have their own advantages and disadvantages. They are described below for the medical staff to choose a more reasonable operating room.

Chlorine-containing disinfectant refers to a hypochlorous acid disinfectant that is soluble in water. Its main component is available chlorine, which has strong microbicidal activity. Because the molecular weight of hypochlorous acid is relatively small, it is easy to penetrate the cell membrane into the bacteria's bacteria, and the bacteria are destroyed by oxidizing the bacterial protein [9]. The chlorine-containing disinfectant has a strong sterilization effect, and is mainly used to kill various pathogenic microorganisms, such as viruses, bacterial propagules, spores, fungi, and the like. However, the chlorine-containing disinfectant is unstable after being dissolved in water, and is easily affected by light, moisture, and temperature, resulting in loss of the active ingredient of the chlorine-containing disinfectant [10]. At the same time, chlorine-containing disinfectants can also corrode and bleach the metal. If the disinfectant is exposed to it for a long time, it will damage the patient's skin and lead to bacterial resistance [11].

The quaternary ammonium salt is also called a quaternary ammonium salt, which refers to a salt substance formed by replacing four hydrogens in the ammonium ion with a hydrocarbon group. The quaternary ammonium salt substance has various functions, but its main function. It is a remarkable bactericidal performance [12]. The double-chain quaternary ammonium salt disinfectant has higher stability than the previous single-double quaternary ammonium salt disinfectant, improves the effect 
of the quaternary ammonium salt disinfectant, and reduces the drug concentration during disinfection [13]. Double-stranded quaternary ammonium salt disinfectant has been a hotspot of research and innovation in medical institutions at home and abroad, and has made remarkable progress, mainly in the extremes of its sterilization, performance, and influencing factors. The main mechanism of sterilization of double-stranded quaternary ammonium salt disinfectant is to destroy the cell wall of bacteria, affect the metabolism of cells, and inhibit the activity of related enzymes. Double-stranded quaternary ammonium salts are easily adsorbed due to their positive charge. On negatively charged bacteria, penetrating the cell wall and acting on the relevant enzyme system in the cytoplasm, the bacterial respiratory function is inhibited, eventually leading to cell membrane lysis and death [14-15]. Therefore, it can be used for disinfection and sterilization of various operating room items such as ventilators, shadowless lamps, monitors, etc., and also has the advantages of colleges, odorless, and no damage to disinfected articles.

In this study, two different disinfection methods were applied to the surface of the same object. The results showed that the number of colonies of the two disinfectants immediately after disinfection, 30 min and $1 \mathrm{~h}$ was significantly lower than that before disinfection $(\mathrm{P}<0.05)$; The number of bacterial colonies of quaternary ammonium salt disinfectant wipes at each time point after disinfection was significantly lower than that of chlorine-containing disinfectants, the difference was statistically significant $(\mathrm{P}<0.05)$; the double-stranded quaternary ammonium salt disinfectant wipes against E. coli, Staphylococcus aureus is better than chlorine-containing disinfectants. The cost of containing a double-stranded quaternary ammonium disinfecting wipe is less than the cost of a chlorine-containing disinfectant per disinfection. The above results show that the disinfection wipes containing double-stranded quaternary ammonium salts have achieved better disinfection effects.

To sum up: when disinfecting and disinfecting the surface of the operating room, double-stranded quaternary ammonium disinfectant wipes and chlorine-containing disinfectants can achieve better results, but disinfection of double-stranded quaternary ammonium disinfectant wipes The effect is better than the chlorine disinfectant, and it has the advantages of low cost, simple and convenient, and is worthy of being promoted in the operating room.

\section{References}

[1] Zhang Dongmin, Jia Guihua, Ding Yongli. Monitoring and analysis of disinfection effect in Xuchang City Hospital from 2004 to 2008[J]. Chinese Journal of Health Laboratory Technology, 2010,36 (04): 850-851.

[2] Li Mengni, Qiu Meng, Zhong Fang. Monitoring and analysis of disinfection effect in hospitals [J]. Chinese Journal of Hospital Infectious Diseases, 2013,34 (08): 1863-1864+1922.

[3] V. Sigler, S. Hensley. Persistence of mixed staphylococci assemblages following disinfection of hospital room surfaces[J].Journal of Hospital Infection, 2013, 83 (03): 253-256.

[4] Song Wenchong, Liu Feng, Qiao Xiuli, et al. Comparison of disinfection effects of two disinfection methods on electronic bronchoscope[J]. Chinese Journal of Disinfection, 2015,32 (03): 290-291.

[5] Dong Fengying, Chai Juan, Wu Ya. Evaluation of disinfection effect of disposable medical disinfectant wipes on the surface of objects[J]. Chinese Journal of Nosocomiology, 2013, 23(03): 615-616.

[6] Zhu Guishuang. Observation on the cleaning effect of different cleaning methods on supply room instruments[J]. Chinese Journal of Practical Nursing, 2006,12 (16):55-56.

[7] Yanwei Shi, Wencui Ling, Zhimin Qiang. A comparison of disinfection by-products formation during sequential or simultaneous disinfection of surface waters with chlorine dioxide and chlor(am)ine[J].Environmental Technology, 2013, 34 (09) : 1191-1198. 
[8] Ni Jie, Lin Lin, Li Guanghui. Clinical application effect and use cost observation of Jielijia medical surface disinfection towel [J]. Chinese Journal of Nosocomiology, 2014, 26 (10): 2581-2583.

[9] Wu Suxian, Li Chunfeng, Ma Sumin. Experimental study on disinfection and rust prevention of metal instruments with chlorine disinfectant [J]. Chinese Journal of Practical Nursing, 2005, 14 (23): 41-42.

[10] Zhang Shumin, Feng Liyuan, Li Min, et al. The effect of two disinfection methods on the surface disinfection of objects around the bed unit [J]. Chinese Journal of Disinfection, 2015, 32 (01): 91-92.

[11] Bieńkowski Marcin, Gospodarek Eugenia, Olejarz Aleksander. The evaluation of skin disinfection efficacy and its influence on prevalence of surgical site infections in the intro laparoscopic cholecystectomy [J].Medycyna Doswiadczalna i Mikrobiologia, 2007, 59 (02): 183 $-191$.

[12] Dong Yuanyuan, Tian Cheng, Zhou Lei. Evaluation of the disinfection effect of double-stranded quaternary ammonium salt disinfectant on the surface of endoscopic central objects [J].Tianjin Nursing, 2014, 22 (05): 441-442.

[13] Liu Xuejun, Lu Wenjin, Zhang Ling. Clinical observation of disinfection effect of hemodialysis machine [J]. Chinese Journal of Nosocomiology, 2014, 24 (01): 245-246, 249.

[14] KE Yajuan, XU Chenxi, YU Shiwa.Application of Long-chain Quaternary Ammonium Disinfectant Spray in Disinfection of Operating Room Air Conditioning Filter[J].Chinese Journal of Disinfection, 2009,23 (01): 108.

[15] Fu Yanhui, Zeng Xiuping. Analysis of bacterial detection and disinfectant effect on the surface of infusion infusion room [J]. Modern Diagnosis and Treatment, 2014, 39 (11): 2588-2589. 